\title{
FEDERAL INCOME TAX: ACCRUAL DATE OF DIVIDENDS FROM STOCK GIVEN IN AN INTRA-FAMILY TRANSFER
}

$\mathbf{P}$ bill is to deflect the father's income into the hands of his children who, having. little or no income of their own, are taxed on the deflected income at a rate considerably lower than that which would have been applied to the income had it been realized by the father. ${ }^{1}$ However, there are severe limitations on the success of such efforts. It was early established that the tax law will disregard the efforts of the taxpayer to assign the income from his personal services. ${ }^{2}$ Similarly, a taxpayer cannot shift the tax liability on income from income-producing property ${ }^{3}$ by giving away the right to the income unless he also gives the incomeproducing property, divesting himself of all the incidents of ownership before the income in question is earned. ${ }^{4}$ Even if the donor gives both the income and the income-producing property, he is none-the-less taxed on any income earned before the making of the gift. However, if the cash basis taxpayer is willing to part with the income-producing

\footnotetext{
${ }^{1}$ See, e.g., Bishop v. Shaughnessy, 195 F.2d 683 (2d Cir. 1952); Overton v. Commissioner, I62 F.2d 425 (2d Cir. 1944); Mahaffey v. Helvering, 140 F.2d 879 (8th Cir. 1944). Since 1944, income of a child is taxable to the child even if, by the local law, it is effectively the property of the parent, INT. REV. CODE OF 1954, § 73, and even though parents remain liable for any unpaid tax owed by a child, INT. REv. CODE OF $1954, \$ 6201$ (c).

Before the income-splitting provisions now found in INT. REV. CODE OF 1954, § 2 were first enacted in I948, many attempts to split income with the spouse were made for the same reasons. See generally, Paul, Restatement of the Law of Tax Avoidance in Studies IN FEderal TAXation 150-5I (1937). The cases dealing with these attempts are quite applicable to attempts to deflect income to children. See, e.g., Lucas v. Earl, 28 I U.S. In (1930).

It is a suggestion of loug standing that the spirit of the 1948 amendment be extended to taxing the entire family as one income-producing unit, see Bruton, The Taxation of Family Income, 4I YALE L.J. 1172 (1932).

${ }^{2}$ Lucas v. Earl, 28 I U.S. III (1930), the genesis of the now famous horticultural metaphor which instructs that the fruits of labor are not to be "attributed to a different tree from that on which they grew." See Jones v. Page, I02 F.2d 144 (5th Cir.), cert. denied, 308 U.S. 562 (1939). See also Rev. Rul. 71, 1953-1 CUM. BuLl. 18.

${ }^{3}$ Helveriug v. Horst, 3 II U.S. II2 (1940); Griffiths v. Commissioner, 308 U.S. 355 (1939), Comment, 38 Mich. L. Rev. 1359 (1940); Tavares v. Commissioner, 275 F.2d 369 (Ist Cir. 1960); Bing v. Bowers, 22 F.2d 450 (S.D.N.Y. 1927), aff'd, 26 F.2d 1017 (2d Cir. 1928). See Schlosberg, Income Tax Consequences of the Assignment or Cancellation of a Leasehold, so TAX L. REv. 257 (1955).

'See generally, Harrown, Helvering v. Horst: Some Recent Applications of the Doctrine, N.Y.U. 6TH INST. ON FED. TAX II27 (1948).
} 
property, and does so before the income thereon is earned, such income will be taxed to the donees. ${ }^{5}$

When the income-producing property is corporate stock, the intervention of the artificial corporate entity delays the date upon which a stockholder realizes taxable income from the time the corporate entity realizes a gain until the benefit reaches the stockholder in the form of dividends. However, it has never been clearly established whether dividends reach the stockholder so as to be included in his gross income upon the date of declaration of dividends, the date of record, or the date of payment. ${ }^{\circ}$

In Smith's Estate v. Commissioner, ${ }^{7}$ two men owned most of the stock in a closely held corporation. They each gave a considerable number of shares to certain of their children after the corporation had declared dividends but before the date of record. ${ }^{8}$ The children received the dividends and included them in their incomes for that year. The Commissioner treated the receipt of dividends by the children as realization of income by the fathers and assessed a deficiency.

The Tax Court, ${ }^{9}$ by a very questionable construction of the applicable state law, ruled that the dividend income had vested in these taxpayers at the date of declaration. ${ }^{10}$ The court then found that the

${ }^{5}$ INT. REv. CODE OF 1954, $\$$ roz (b). The obvious disadvantageous feature of this means of tax avoidance is that the father completely loses legal control over the incomeproducing property and with it, all too often, the respect and obedience of his children.

'Commissioner v. Cohen, r2r F.2d 348 (5th Cir. 194r), Helvering v. McGlue's Estate, II9 F.2d I67 (4th Cir. I94I), and Estate of Ledyard, 44 B.T.A. 1056 (I94I) (probably distinguishable on the basis of applicable state law), give some support to the declaration date arguments. See generally, Annot., 150 A.L.R. 754 (1944).

More impressive authority supports an argument for a later accrual date. Avery v. Commissioner, 292 U.S. 2 ro (1934), held that dividends do not become income on mere declaration, but only when "received," that is, unqualifiedly made subject to the stockholder's demand as by check. See Treas. Reg. § I.301-r(b) (1955); Commissioner v. American L. \& T. Co., r 56 F.2d 398 (7th Cir. 1946); Tar Products Corp. v. Commissioner, 130 F.2d 866 (3d Cir. 1942); Annot., 143 A.L.R. 596 (1943). ${ }^{2} 292$ F.2d 478 (3d Cir. 196r), cert. denied, 82 Sup. Ct. 438 (1962).

${ }^{8}$ The company and the commissioner entered into a final agreement on March 25, 1953, establishing the company's liability for the personal holding company surtax and allowing the company to obtain a credit against the tax and thus to free itself of most of the deficiency by declaring a deficiency dividend. Electing to take advantage of this agreement, the directors on April 17, 1953, declared dividends to be paid on May ro, 1953, to the stockholders of record on that date. The petitioners gave the stock to their children on May 9, 1953.

34 T.C. 842 (1960).

${ }^{10}$ The Tax Court's underlying premise, perhaps itself open to question, see Estate of Putnam v. Commissioner, 324 U.S. 393, 395 (1945); Lyeth v. Hoey, 305 U.S. 
taxpayers' act of giving away stock upon which dividends had been declared was an anticipatory assignment of fully-vested income, with the result that the taxpayers remained liable for the tax. That a stockholder receives no right to immediate possession until the date of record and only then if he has retained the ownership of the stock was depreciated by the court as "a mere convenience either for their supposed benefit or for the benefit of the corporation." "11

Clearly, a finding that the taxpayers had a fully-vested right to these dividends prior to the making of the gift and that the record date created no real condition ${ }^{12}$ to their enjoyment of this right was essential to the relevance of both the commissioner's successful theory of anticipatory assignment ${ }^{13}$ and his alternative argument that the taxpayers were

$188,193(1938)$, was that the state law establishes the property rights of the parties and the federal law merely attaches the tax consequences. The successful contention of the Commissioner was that under the New Jersey law the effect of declaration is to constitute the corporation as the debtor of its stockholders and thereby to give each stockholder an immediately-vested right to a future payment of dividends. The taxpayer contended that the authority the Commissioner cited in support of his view that a stockholder's rights to dividends vest at the declaration date were cases in which the declaration failed to provide for a date of record. But granted the correctness of the Tax Court's construction of state law, the concept of vesting, at least to the extent based on a finding of the establishment of a debtor-creditor relationship, would not be considered helpful by the majority of courts. Most courts find that a taxpayer realizes dividend income only when it is made unqualifiedly subject to his demand. See, e.g., Commissioner v. American Light \& Traction Co., 156 F.2d 398 (7th Cir. 1946).

${ }^{11} 34$ T.C. 842,844 (1960).

12 The situation here is not strictly analogous to an assignment of accrued bond interest, rents, royalties, etc. These items are taxable to the holder of the income producing property to the extent the income thereon is earned while held by the donor without regard to the dates the income becomes unconditionally payable, because, except for the passage of time, nothing further need be done by the taxpayer to realize income. Helvering v. Horst, 3 II U.S. II2 (1940). But these items are said to accrue day-byday regardless of when they fall due. Dividends do not accrue day-by-day. The stockholders have granted power over their investment to the corporate director and have no right to a return until dividends are declared. Thus, if a bond and all outstanding interest thereon were given away two days before the interest fell due, two day's interest would be substracted from the amount of income taxable to the donor. If stock were given away two days before the recórd date established by a prior declaration of dividends, two day's dividend income clearly could not be subtracted from the donor's gross income.

${ }^{13}$ One has made an anticipatory assignment of income when he assigns to another his vested right to receive income. Commissioner v. Sunnen, 333 U.S. 59r, 604 (1948). If it were established that the dividends accrued on the date of declaration, or on some other date prior to the making of the gift, a discussion of anticipatory assignment would be relevant to explain how it is that a cash basis taxpayer received taxable income without receiving cash or a cash substitute. But until it is established that the right to income has vested in the taxpayer, any discussion of anticipatory assignment is premature. It is true that making an anticipatory assignment of income in- 
in constructive receipt ${ }^{14}$ of the dividends. Therefore, the Tax Court's decision can be upheld only by adopting that court's ruling that these dividends vested at the date of declaration. ${ }^{15}$ One may question the relevance of the concept of vesting to a tax law which boasts its lack of concern with the "attenuated subtleties" of the law of property. ${ }^{18}$ With or without the concept of vesting, however, it is clearly the weight of authority that dividends do not accrue until the date of record. ${ }^{17}$

volves the exercise of power over the income and the commanding of its benefits. See Helvering v. Stuart, 3 I 7 U.S. I54 (1942). But it does not follow from this that one who exercises such power over income has made an anticipatory assignment. See Bishop v. Shaughnessy, I95 F.2d 683 (2d Cir. x952). Power over income and the ability to command its benefits does not depend on vesting. For example, such power is exercised by a stockholder who transfers his stock before dividends are declared but this exercise of the power to command benefits would not be considered an anticipatory assignment by any court.

${ }^{14}$ Constructive receipt is a theory utilized to impose a tax on a cash basis taxpayer who, in order to delay the realization of income until a subsequent tax year, has declined to accept dominion over income which is, except for some self-imposed condition, completely within his control. The Commissioner's constructive receipt argument assumes that the record date is self-imposed and therefore not a real condition to the donor's inmmediate enjoyment of the dividend income at the time he surrendered ownership and control of the stock. Such an assumption ignores the very corporate structure that gives rise to the tax. The taxpayer contended that the record date is not a condition self-imposed by the taxpayer, but a condition imposed upon the taxpayers by the corporate entity. See generally Treas. Reg. $\$ 451-2$ (I957); Commissioner v. Fox, 2 I 8 F.2d 347 (3d Cir. r954).

${ }^{18}$ See Harrison v. Schaffner, $3 \times 2$ U.S. 579 ( $\left.\times 94 x\right)$, where in speaking of Helvering v. Horst, $31 \times$ U.S. I 12 (1940) and Helvering v. Eubank, 311 U.S. 122 (r940), and failing to make a possible decisive distinction in the facts, the Court said "in each of those cases it was held that one vested with the right to receive income did not escape the tax by any kind of anticipatory arrangement, however skillfully devised, by which he procures payment of it to another, since, by the exercise of his power to command the income, he enjoys the benefit of the income on which the tax is laid." 312 U.S. at 582 [Emphasis added]. "[O]ne who is entitled to receive, at a future date, interest or compensation for services . . . realizes taxable income quite as much as if he had collected the income and paid it over to the object of his bounty." II. at 580 [Emphasis added].

In all the anticipatory assignment cases, either the event making the income taxable to the assignor had already happened at the time of the attempt to deflect the income, Helvering v. Horst, supra; Austin v. Commissioner, I6I F.2d 666 (6th Cir. 1947); Annie A. Colby, 45 B.T.A. 536 ( $194 \mathrm{I}$ ), or the assignor retained meaningful control over the income-producing property at least sufficient to affect the amount of income produced. Helvering v. Stuart, 317 U.S. 154 (1942) (taxpayers used their control of the stock as trustees under a trust arrangenient for their donees to maintain their control over their corporation).

${ }^{10}$ See, e.g., Lucas v. Earl, $28 \mathrm{I}$ U.S. xi (1930) and note ro, supra.

${ }^{17}$ The Supreme Court in Putnam v. Commissioner, 324 U.S. 393, 399 (r945), clearly restated the law in this regard: 
- On appeal, the Court of Appeals for the Third Circuit failed to resolve the dividend accrual date controversy. Rather that court affirmed the decision for the Commissioner in a totally unsatisfactory opinion in which it erroneously thought itself bound by the Supreme Court decision in Helvering v. Horst. ${ }^{18}$ In that case, the taxpayer had given bond coupons to his son and the son had cashed them at maturity. The donor was held taxable on the interest income collected by the son because the father had retained ownership of the bond, the income producing property. In the instant case, however, the stock was given along with the expectancy of income. The court thought that the importance of this factual distinction had been erased by the Tax Court decision in Estate of Bertha May Holmes. ${ }^{10}$ There the taxpayer was found taxable on credited accumulated dividends which she had given to her children along with the stock. In the Holmes case, like the Horst case, the income had clearly accrued to the donor before the gift of income-producing property was made. Only by assuming the correctness of the Tax Court's questionable finding that the dividends accrued to the Smith case taxpayers at the declaration date, the very issue on appeal, can that case be said to be controlled by the Horst case as modified by the Holmes decision.

The Court of Appeals adverted to Putnam v. Commissioner, ${ }^{20}$ wherein the Supreme Court held that when the taxpayer dies between the date of declaration and the date of record, the dividends are includable in the return filed by the taxpayer's estate rather than the return filed for the decedent for the last part-year of his life. The court concluded that this authority was not controlling, since it addressed itself to the question of when the income accrued, rather than to whom it accrued. It seems, however, that the two questions are inseparable, for to ascertain to whom income is taxable, one must ask when the income accrued and then determine the owner of the income-producing property at that moment. A man's estate is, for tax purposes, a completely

"Earnings, before declaration of dividends, while increasing the value of his stock, have never been treated as an event to mark taxable income to the stockholder. Mere declaration of a dividend does not alter the stockholder's interest in the corporate assets. ... The stockholder can acquire no interest in a dividend, amounting to an accrual under section 42, [Revenue Act of 1938] before the amount of the dividend and the distributee is determined." [Emphasis added.]

${ }^{28} 3$ II U.S. 112 (1940). See also Corliss v. Bowers, 28 I U.S. 376 (1930) (concerning income-producing property given by a revocable trust).

${ }^{10}$ I T.C. 508 (1943).

${ }^{20} 324$ U.S. 393 (1945). 
separate entity. Therefore no sound distinction can be made between the legal effect of the movement of stock ownership from a man to his donee and from a man to his estate. Consequently, the practical effect of such a distinction is to create a new rule as to when dividends accrue applicable only in a gift context.

Furthermore, though the court thought this departure from the Putnam rule was dictated by "practical considerations of fairness and convenience," 21 the rule suggested in the Smith case achieves neither result. The owner of a given share of stock, and thus the person liable for income tax on any dividends it produces, is more easily ascertained on the record date than on the declaration date. The closing of the transfer books for a period encompassing the record date, for example, though intended to facilitate the corporation's determining to whom it is liable for dividends also makes it the more convenient date for the imposition of the tax.

Moreover, the Third Circuit's rule as to the time when dividends accrue on donated stock does not thwart tax avoidance, for a controlling stockholder may still avoid the tax by giving away the stock before he causes his corporation to declare dividends. Such a rule actually invites unfairness for it gives a special advantage to those inside persons who may have advance notice of an impending declaration of dividends. ${ }^{22}$

Finally, the Commissioner need not be apprehensive of this seeming tax loophole, for the obvious disadvantage of one's giving away his property to avoid a tax on it and the fact that this method of avoidance can be utilized but once for each of a man's possessions, necessarily limits its threat to the federal revenues to near insignificance.

From the decision it is not altogether clear whether the Court of Appeals considered itself bound by Helvering $v$. Horst because of the supposed parity of the facts, or because of the concept of "taxable satisfaction" which finds its classic statement in that case. ${ }^{23}$ If the latter,

21292 F.2d at 480 .

${ }^{22}$ Complete fairness in this regard can only be achieved by taxing corporate income to stockholders as it is realized by the corporation. Whether a corporate stockholder can, under the sixteenth amendment, be taxed on undistributed income is questionable, Eisner v. Macomber, 252 U.S. 189 (1920), not to mention the obvious difficulty of administrating such a plau.

${ }^{23}$ Helvering v. Horst, 311 U.S. II 2 (1940). In taxing the proceeds from the redemption of donated coupons to the donor bondholder, the Supreane Court said: 'Even though he never receives the money, he derives inoney's worth from the disposition of the coupons which he has used as money or inoney's worth in the procuring of a satisfaction which is procurable only by the expenditure of money or money's 
it seems unfortunate that the Third Circuit saw fit to breathe new life into this superfluous doctrine. ${ }^{24}$

In assessing the usefulness of the satisfaction concept, it is first necessary to divide the theory into its component parts, "economic satisfaction" and "personal satisfaction." If each of the taxpayers in the Smith case had arranged to have the dividends paid to his creditors in discharge of a debt, ${ }^{25}$ to minor children in discharge of his duty of support, ${ }^{26}$ or even toward the purchase of a policy of life insurance payable to his children in performance of his moral obligation to them, ${ }^{27}$ a real economic gain would have accrued to the taxpayers. ${ }^{28}$ This gain may be labeled "economic" satisfaction, though a more descriptive appellation would be "indirect realization of income." If, on the other hand, the taxpayers had arranged to have the dividends paid to charity or to a favorite nephew, the gain would be non-material and the satisfaction purely "personal." Although this dichotomy is not clearly distinguished in the decisions, satisfaction in the latter sense has never been used to find taxable income. ${ }^{29}$ Furthermore, courts have not used it in determining whether the donor or donee is taxable on income clearly taxable to one of them, but rather only to demonstrate the reasonable-

worth. The enjoyment of the economic benefit accruing to him by virtue of his acquisition of the coupons is realized as completely as it would have been if he had collected the interest in dollars and expended them...." Id. at I I7.

"At one time it was widely felt that a satisfaction criterion would have great utility in simplifying the task of determining the person to whom income is taxable. But the idea soon lost favor with courts and commentators as producing more problems than it solved and few regretted its ebbing, see generally, Soll, Intra-Family Assignments: Attribution and Realization of Income, 6 TAx L. REv. 435 (I95I).

${ }^{25}$ U.S. v. Boston \& Maine Railroad Co., 279 U.S. 732 (1929); Old Colony Trust Co. v. Commissioner, 279 U.S. 716 (1929); cf. U.S. v. Mahoning Coal Railroad Co., 51 F.2d 208 (6th Cir. 193I). See, U.S. v. Kirby Lumber Co., 284 U.S. I (I93I); Bowers v. Kerbaugh-Empire Co., 27 I U.S. I7o (1926).

${ }^{16}$ Helvering v. Stokes, 296 U.S. 551 (1935) (per curiam); Douglas v. Willcuts, 296 U.S.' 1 (1935) (in discharge of duty to pay alimony). See, Anthony's Estate v. Commissioner, I55 F.2d 980 (1oth Cir. 1946). The relevant section today is INT. REv. CODE OF $1954 \$ 677$ (b).

${ }^{27}$ Burnet v. Wells, 289 U.S. 67o (1933) (Cardozo J.).

28 "[E]conomic gain realized or realizable by the taxpayer is necessary to produce a taxable income....." Helvering v. Stuart, 3 I7 U.S. 154, 168 (1942), wherein it was held that the creator of a trust for his daughter is not taxable on the income produced by the trust even though it "would satisfy the normal desire of a parent to make gifts to his children."

"See generally, Rice, Judicial Trends in Gratuitous Assignments to Avoid Federal Income Tax, 64 YALE L.J. 991 (1955). 
ress of their imposition of the tax upon the donor under some other rationale. ${ }^{30}$

In the Smith case, the donees were adult children toward whom the donors had no duty of support. Accordingly, the donor's satisfaction did not take the form of economic gain, but was a purely personal satisfaction. If the Court of Appeals is urging that personal satisfaction is sufficient in itself to cause the dividends to be taxable to the donors, the rule of the case is administratively unmanageable ${ }^{31}$ and if applied consistently would be greatly disruptive of our tax laws. ${ }^{32}$ If on the other hand, the court employed personal satisfaction as a corrobora-

${ }^{30}$ Indeed, the satisfaction doctrine found its first expression in Burnet v. Wells, 289 U.S. 670 (1933), where the Supreme Court sought to demonstrate that a tax, incontrovertibly imposed upon the petitioner by the statute, was not, as claimed, so arbitrary as to be an unconstitutional taking of property without due process of law.

${ }^{31}$ If satisfaction really were the test of what person is taxable on income, the court need not have concerned itself with the declaration date any more than it did with the record date. The taxpayer would receive equal satisfaction from assigning stock with a sizable surplus available for distribution as he would from assigning stock upon which dividends had been declared. Conversely, if the Treasury were to attach income tax consequences to the feeling of a "twang" of satisfaction, how would it tax a man who was in a coma when his corporation declared and paid dividends and who did not awaken until his next fiscal year? Would this be "constructive" satisfaction?

Or, assuming the reasonableness of a taxable satisfaction theory, should the realization of income come to the donor upon the making of the satisfying gift or upon otbaining the satisfaction of seeing the donee receive the benefit, i.e. when the dividends are received? In the Smith case, the court apparently thought taxable satisfaction occurred at the making of the gift. In Commissioner v. Timken's Estate, 141 F.2d 62.5 (6th Cir. 1944), the taxpayer gave to a charity certain notes upon which the debtor had not nor could not pay the interest accrued or to accrue. The court held that no tax was incurred by the taxpayer at the time of the gift (or, for that matter, when the debtor eventually paid off the notes, for by then, said the court, the charity was the full owner). Cf., Helvering v. Eubank, 311 U.S. 122 (1940); Anthony's Estate v. Commissioner, 155 F.2d 980 (roth Cir. 1946); Annie A. Colby, 45 B.T.A. $536(194 \mathrm{X})$.

s2 Such a use of a satisfaction concept would, if applied consistently, seem to demand the levying of a tax on the satisfaction flowing to a homeowner upon the enjoyment of his house (as is done in England). To attempt this would raise serious constitutional questions. See Helvering v. Independent Life Ins. Co., 292 U.S. 371, 379 (1934) (dictum).

And would not the same satisfaction accrue to one who gives property greatly enhanced in value (as stocks in a corporation which has accumulated a substantial earned surplus or farm products which have had a tax free maturation) is given to charity? But it seems to be settled at last that the giving away of property does not produce taxable income. Cambell v. Prothro, 209 F.2d 351 (5th Cir. 1954); Elsie SoRelle, 22 T.C. 459 (1954) (land given away one week prior to harvest of wheat crop worth $\$ 50,000,00)$; Estate of W. G. Farrier, I5 T.C. 277 (1950) (rejecting I.T. 3932, r 948-2 Cum. Bull. 7). 
tive justification for its holding that the income accrued at the declaration date, the use of personal satisfaction only beclouds the real issues. When the income-producing property is given with the income, the only real issue is whether the income accrued before or after the making of the gift.

The Commissioner's position in the Smith case had unusual appeal because the transfer in question was obviously a mere shifting of wealth within the taxpayers' families in an effort to minimize the tax on dividends allowed by the Service as a credit against a personal holding company surtax assessment. ${ }^{33}$ Perhaps some special provision should be added to the Internal Revenue Code to deal with this manner of avoiding a tax on deficiency dividends or to deal with tax avoidance by intra-family transfers in general. In any event, the resolution of this problem should not be attempted by the manipulation of such concepts as taxable satisfaction, anticipatory assignment, or constructive receipt. Clearly, adopting the declaration date as the date upon which dividend income accrues would not appreciably lessen this manner of tax avoidance. The most convenient date for affixing income tax liability and the date best supported by reason and precedent is the date of record.

\footnotetext{
${ }^{38}$ The facts are summarized at note 8 supra.
} 